\title{
Visualising a minority language community? Visual art and Community Festivals in the Connemara Gaeltacht $(2010-2015)$
}

Nuala Ní Fhlathúin

Nuala123@gmail.com

Galway-Mayo Institue of Technology

To cite this paper: FHLATHÚIN, Nuala Ní - Visualising a minority language community? Visual art and Community Festivals in the Connemara Gaeltacht $(2010-2015)$. Estudo Prévio 15. Lisboa: CEACT/UAL - Centro de Estudos de Arquitetura, Cidade e Território da Universidade Autónoma de Lisboa, 2019. ISSN: 2182-4339 [Available at: www.estudoprevio.net]. DOI: https://doi.org/10.26619/2182-4339/15.2/

Received on 3 February 2019 and accepted for publication on 3 June 2019.

Creative Commons, licence CC BY-4.0: https://creativecommons.org/licenses/by/4.0/

\begin{abstract}
Recent work by scholars of Irish Studies has established the significance of images of the West of Ireland in the fields of visual arts and literature. However, the discourse surrounding these arguments has been produced from an Anglophone perspective, defining the West as an undifferentiated "other", signifying an idealized and romanticized Irishness. My research extends the scope of this discourse, examining visual art production in the West of Ireland in the light of specific local cultural contexts, in this case the bilingual context of community arts festivals in the rural Connemara Gaeltacht (Note: Gaeltacht refers to an area where Irish is in use as a primary community language). Specifically, in my project, I will be looking at the activities of two community arts festival in the Coisfharraige coastal area (2010 - 2015) in order to bring to the fore complex roles played by visual art activities within a nuanced Gaeltacht context. In doing so I draw on literature from the fields of Irish Studies, Place-based Art Studies and Festival Studies to argue that tensions around language and identity have strongly influenced visual art production in the Gaeltacht.
\end{abstract}

Keywords: Gaeltacht, Community Festivals, Visual Arts, Irish Language 


\section{Introduction ${ }^{1}$}

Recent work by scholars of Irish Studies (most notably Catherine Nash, Luke Gibbons, and Yvonne Scott) has established the significance of images of the West of Ireland in the fields of visual arts and literature. However, the discourse surrounding these arguments has been produced from an Anglophone perspective, defining the West as an undifferentiated "other" in the visual and academic language of the mainstream Irish art world, and thereby obscuring alternative cultural contexts offered by Irish speaking communities on the West coast of Ireland. One means of extending the scope of this discourse is to examine visual art production in the West of Ireland in the light of specific cultural contexts, in this case the bilingual context of the rural Connemara Gaeltacht (Note: Gaeltacht is the name given to bilingual areas in Ireland where the Irish language is still widely spoken as a community language). To this end, this essay focuses on the role of community festivals in the Connemara Gaeltacht in shaping visual art discourse in the area. (In the absence of other infrastructure, these festivals have played a significant role in providing a platform for the visual arts). ${ }^{2}$ It explores the recent relationship between these festivals and contemporary visual art practices, an area not previously subject to sustained critical attention. It is innovative in its emphasis on the rural Gaeltacht as a discursive frame for contemporary visual arts, and in its focus on the Irish language as an important aspect of site specificity in a contemporary visual art context.

My work focuses on the activities of two local festivals in the Coisfharraige coastal area, Féile Pléaráca and Féile Tradphicnic, during the years 2010-2015. It uses a combination of methodologies, drawing on archival research and fieldwork alongside a consideration of my own personal experience as a contemporary artist practising in the Gaeltacht. It investigates and analyses recent archival material related to the presentation of the contemporary visual arts in a festival context, and accesses unarchived information relating to this topic through interviews with key figures in multidisciplinary community arts organisations. Key areas of analysis include the format of visual art presented, the types of venues chosen by organisers, and their motivations for incorporating the visual arts in festival programming. I also consider the impact of the organisational structure and cultural remit of the hosting festivals. Interviews were semi-structured and conducted one-to-one, and the documents consulted were sourced from informal festival archives held by festival committee members. In carrying out this research, I occupy the role of an observant participant, using an existing role to research situations already familiar to me (Brewer 2005) in both a personal and professional capacity. Having exhibited artwork in both festivals in question, I continue to be involved in the local art scene, as an exhibiting artist, as a participant in the Gaeltacht Community, and as an Irish-speaking community activator who plays a developmental role in the visual arts in the Gaeltacht. 


\section{The rural Gaeltacht: linguistic and cultural concerns}

This research is based in the Connemara Gaeltacht, in the province of Connaught on the West coast of Ireland. Connemara contains the largest of the rural Gaeltacht areas in Ireland, the predominantly Irish-speaking areas which were formally defined in 1926 as part of early government-led language revival initiatives to combat the decline of Irish. In his overview of the Irish language revival movement, Donncha Ó hÉallaithe traces the effects of governmental policy in Gaeltacht and non-Gaeltacht areas from 1923 onwards (Ó hEallaithe, 2004). It is clear that even as the language revival movement (aided by reforms in the educational system) gained some ground in the rest of the state, the number of Irish speakers in Gaeltacht areas continued to decline. This decline was compounded by mass emigration from the Gaeltacht areas, a discrepancy between the high constitutional status accorded to the Irish language, and the reality of the many social and economic difficulties faced by monolingual Irish speakers in Gaeltacht areas. Approximately 10,000 emigrants left the Connemara Gaeltacht from 1946 to 1966 . Difficulties faced by monolingual Irish speakers include the predominance of English monolingual industries encouraged by governmental policy in Gaeltacht areas, and the difficulty of accessing services through the Irish language from the state itself (Ó hÉallaithe, 2004).

In tandem with concerns over language shift, the co-option of Gaeltacht culture in tourist narratives has been perceived as a threat to the vitality of these Irish-speaking areas. John Walsh, a scholar of Irish studies, details widespread concerns surrounding the commoditization of minority cultures, and the idealization of the Gaeltacht as both a tourist destination and a percieved locus of true Irishness, or as Walsh aptly phrases it, "...the well of language and Irishness (tobar na teanga agus an Éireannachais)" (Walsh, 2011:10). Gearóid Denvir, analysing the effects of tourism in Gaeltacht areas, argues that narrow market-led tourist-driven definitions of cultural events lead to a commercialization and ultimately a freezing of culture, which comes to be seen as "a product rather than as a system of values, beliefs, practices, and norms which give meaning and value to a society." (Denvir, 2002: 28) In his view, cultural events staged for tourists have the effect of reducing history and culture to "remnants of an almost forgotten past or to mere local colour to be performed for outsiders, in the end duping both the community and the tourist" (Denvir, 2002: 28). Its clear that, alongside issues of language decline, cultural activity in the Gaeltacht in a more general sense acts as a catalyst for concerns around authenticity as a quality that can be variously staged, projected, commoditized, depleted or usurped.

Nine decades after 1923, the issue of language decline in Gaeltacht areas continues to generate concern. ${ }^{3}$ However, as Walsh points out, limited research has been carried out on the cultural consequences of this decline, with little engagement with Irish as a contemporary language with "real speakers, in real communities" (Walsh, 2011:12). This lack of engagement with Irish language contexts is evident in the dominant academic discourse around the visual arts. An established body of literature in the field of Irish Studies has framed the West of Ireland through the lens of postcolonialism, with scholars such as Catherine Nash, Deirdre O'Mahony, Luke Gibbons and Yvonne Scott 
arguing for the significance of images of the West in the fields of visual arts and literature. However, their work has adopted an Anglophone perspective, largely defining the West as an undifferentiated "other" in the visual and academic language of the mainstream Irish art world. In their readings, iconic images such as Paul Henry's paintings of West of Ireland landscapes function as a shorthand for an authentic Irishness, a symbol of the New State, widely used in tourist brochures (Scott, 2005: 6). Neither these lonely images nor the current critical discourse that surround them contain traces of a culturally proactive Gaeltacht community, nor echoes, however faint, of a living, evolving language.

\section{Art and Place}

Wider theorisations of the relationship between art and place focus on complex dynamics between artmaking, community identity, and changing definitions of place. This politicisation of public space as contested, constructed territoriy draws on a corpus of ideas that the theorist Rosalyn Deutsche refers to as a "spacial-cultural discourse", examining how artistic practices arise out of, and intersect with spatial politics. (Deutsche,1996: xi) Miwon Kwon, a theorist and curator, explores the evolving relationship between artwork and place from the 1960s onwards, tracing the rise of place as both a creative prompt and contextualising frame for the visual arts. (Kwon, 2004) Her research emphasises the ongoing influence of actual physical places in a global, dematerialised world, arguing that "the phantom of a site as an actual place remains, and our psychic, habitual attachments to places regularly return as they continue to inform our sense of identity" (Kwon, 2004:108) Her work provides a conceptual underpinning for my research, and my consideration of the Gaeltacht as both a physical and discursive site in which to examine art-making in a community context.

In Kwon's work the relationship between art and place is shown as complex, caught in the push and pull of different political conceptions of place. As with Denvir and Walsh above, Kwon sees the relationship between art and place as a potentially exploitative one, influenced by motivations of political, financial or reputational gain. ${ }^{4}$ However, conversely, efforts to protect and reaffirm threatened communal identities from outside forces can lead to the social instrumentalization of art in a community context, where art is perceived as a means to a social or political end. Throughout her extended essay and book, Kwon calls for a renegotiation of the relationship between art production and communities, whereby art neither acts as a nostalgic mirage nor fails to acknowledge the social and political constraints of place..$^{5}$ Evolving relationships between art, community and place are further elucidated through curatorial praxis which draws on Kwon's research. Locating the Producers - Durational Approaches to Public Art documents research carried out at five large-scale, durational art projects in Europe (O'Neill, Doherty, 2011). This study examines curatorial models which emphasise longterm community-based projects. The projects chosen could all be considered responses to the challenges and tensions outlined by Kwon, informed by an awareness 
of a need to work from "an informed embedded position", while avoiding a "pseudoethnographic commissioning process" (O'Neill, Doherty, 2011: 3). As in Kwon's research, emphasis is placed on tensions between stable and fluid definitions of place. ${ }^{6}$ Their analysis of the Creative Ergemont project by Grizedale Arts, is of particular relevance to a Gaeltacht context because of its focus on a community in the Lake District, a rural area heavily defined by tourism. Grizedale Arts, an arts organisation that engages with communal and collaborative approaches to art making, see themselves as working outside of romantic and individualistic conceptions of artmaking. ${ }^{7}$

Grizedale projects consciously mimic existing community networks and structures, blurring lines between professional/amateur, paid worker/volunteers, borrowing from the embedded, organic ethos of many community events (O'Neill, Doherty, 2011: 95). To this end, emphasis is placed on the integration of art and social life, and on partnerships with the wider community, while the definition of art as an autonomous object is challenged and priority is given to creating meaning in a local context. ${ }^{8} \mathrm{~A}$ pertinent example of this involved the large-scale organisation of a local festival, to encourage debate and proactive decision-making in a community whose cultural environment has been shaped by tourism (O'Neill, Doherty, 2011: 96). It is impossible in this case to differentiate between festival and artwork as structure and content. We see thus enacted on a practical level the complex engagement between festival staging, art-making and building community.

Such complexity however generates a corresponding level of difficulty in the evaluation and analysis of such projects. As Claire Bishop points out in her reconsideration of critical approaches to the contemporary socially-engaged genre, durational projects are challenging to evaluate using traditional methods of visual analysis, particularly in cases where the upending of aesthetic categories are integral to the structure of the project. In her book "Artificial Hells" she strongly argues against a purely positivist, sociological evaluation of socially oriented art projects, where the critical focus is confined to an evaluation of ethics upheld and social good achieved. Instead she calls for renewed attention to the "modes of conceptual and affective complexity" generated by such projects (Bishop, 2012:8).

\section{Discourses in Festival Studies}

The role of community festivals in fostering the arts (both in Ireland and internationally) is widely acknowledged. This is true in the realms of community animation and audience development, but also in a deeper sense: they support local forms of creative knowledge within a framework that draws on accumulated cultural capital attached to a particular region or place (Quinn, 2006, Del Barrio, 2012, Richards, 2007). In the absence of other infrastructure, ${ }^{9}$ community festivals have played a highly significant role in providing a platform for the visual arts in the Connemara Gaeltacht. ${ }^{10}$ In my own experience, working within the framework of an established festival has many 
advantages for an artist who is looking for an audience outside of the mainstream artworld infrastructure of galleries and museums. Festivals can potentially supply publicity, a readymade audience and logistical assistance whilst acting as community based funding partners. However, as discussed above, the context provided by festivals is by no means straightforward. A wide-ranging overview of literature on festivals offered by Donald Getz points to the complexity of discourses surrounding festivals, and the constructed, communal and politicized nature of festival-making. Getz notes that many definitions exist of what constitutes a festival and that no overarching typology has been agreed upon within the field (Getz, 2010:2). He points out the element of coordinated, managed, politicized activity that is involved in present-day festival organization, and the socially constructed nature of modern festivals, carrying multiple meanings on personal, social and cultural levels. ${ }^{11}$ He recommends a holistic engagement with festivals across a variety of discourses, looking at why, how and for whom they are produced, why they are attended and the wider forces shaping them (Getz, 2010: 20). Getz makes no reference to the significance of festival content, other than to note its potential diversity and its power to shape behaviour and attitudes. However, as with Kwon in a visual art context, he emphasizes the use of festivals as instruments of social and cultural policy (Getz, 2010: 20). Within the arena of festival studies, the idea of festivals as instruments of cultural power is more widely connected with ideas of the dual nature of festivals, as both inward and outward looking, sustaining a particular local vision, while participating in wider flows of economic and cultural activity through tourism (Quinn, 2006, Del Barrio, 2012, Richards, 2007).

Turning to a specifically Irish context, an independent report commissioned by AOIFE (the Association of Irish Festival Events), gathered baseline data to provide an overview and analysis of the Irish festivals movement (Goh, 2004). ${ }^{12}$ This survey reveals useful information on the mechanics of festival organization, with a focus on core issues: finances, volunteering, external relations, development and health \& safety. Venues used by festivals spanned outdoor public space, pubs, local business, schools, community halls, and to a lesser extent church or marquees (Goh, 2004: 7). Festivals rely heavily on community goodwill to fill organisational and technical roles: volunteers played a very significant role in the running of festivals, taking on diverse roles across a spectrum of festival activities, as festival managers, festival programmers, fundraisers, ushers, and technical assistants. Conversely festivals also often "give back" to the community by providing events free of charge. Free events were provided at $89 \%$ of festivals; however only $15 \%$ of respondents promoted free events exclusively.

The survey is less helpful in its consideration of the motivations and aims of festivals. The promotion of "artistic excellence" is the most common response, followed by "increasing tourism", and the more diffuse aim of putting the local area "on the map". Heritage is perceived as an important factor in Irish festivals, with $89 \%$ of respondents agreeing, "Irish festivals contribute to preserving our unique heritage". However, as no analysis is carried out as to what key terms (e.g. "unique heritage", "artistic excellence") signify to either audience or festival organisers the report is of limited use in understanding the relationship between the visual arts and community festivals. The 
rest of this essay considers this relationship by examining the activities of two local festivals in the Connemara Gaeltacht, Féile Pléaráca and Féile Tradphicnic, within the timeframe $2010-2015$.

\section{Methodology}

Interviews, archival research, and a consideration of my personal involvement are used to gain a holistic picture of how the visual arts sit within a community festival context in the Connemara Gaeltacht. This qualitative approach was considered appropriate as my research addresses a wide context (the dissemination of contemporary visual arts in rural Gaeltacht areas) with many variables (variations in traditional festival locations / funding levels / audience numbers / venues / local practices). Interviews were carried out one-to-one and conducted in person, preceded by emails and phone calls beforehand to clarify the nature of the research and the kind of questions I planned to ask. The interviews focused on gaining insights from the in-depth knowledge of cultural producers in relation to the festivals being researched. The interviewees, Bridge Barker and Meta Uí Mháille, were selected for their expertise and experience as key organisational figures in the field of community arts in the Connemara Gaeltacht, and were sourced from the organising committees of two local festivals, Féile Pléaráca and Féile Tradphicnic. Bridge Barker is festival founder and chairperson of Féile Tradphicnic, while Meta Uí Mháille held a position as a community worker for the now defunct Pléaráca organisation and was a festival committee member for Féile Pléaráca.

Interviews were semi-structured, comprising closed response "yes/no" questions and more open-ended questions. This amalgamation of qualitative and quantitative data (quantitative in the sense that the inclusion of closed response questions allows for a direct comparison of multiple sets of answers) is a well-established technique in the qualitative research framework. It allowed for comparisons to be formed between interviews undertaken, but also enabled an exploratory, less controlled approach, allowing new information to surface. The interview process assumed that a focus on broad, open-ended questions regarding choices and rationale in relation to the presentation of the visual arts in festival contexts was the most fruitful way to gain a perception of value, practical considerations, and a broad overview of how the visual arts are situated in this arena.

These two interviewees were also my sources for the archival festival documents examined during this research, a combination of photocopied documents and electronic documents in PDF format, alongside a limited amount of information retrieved from the internet. Archival material was consulted both to gather factual data on contemporary visual art exhibitions in a festival context, and to consider how the visual arts were presented in these documents. Atkinson and Coffey point to the twofold status of documents as both potential sources of factual data, and opaque representational documents that rely on internal conventions and are open to 
interpretation (Atkinson \& Coffey, 2004). Despite this note of caution, documents are interesting as research material because they exist independently of, and prior to, the research process (Silverman, 2006:157). In this instance archival documents were important in providing schedules and descriptions (albeit brief) of festival events, details that might be difficult to accurately recall without material prompts.

My own involvement as an observant participant in this research is a multilayered one. As an artist who has exhibited with both festivals, I can provide a subjective account of that limited experience and contextualise it within new knowledge gleaned from archives and interviews. However, a number of caveats apply here. My first-hand experience of Féile Pléaráca is confined to one exhibition with the festival in Inis Oírr in 2013, whereas I have exhibited with Féile Traidphicnic every year since 2014. I have also over the years assumed an ad-hoc curatorial role with Féile Traidphicnic, so that my aspirations to strengthen the visual arts in the area, and my own artistic interests, strengths and weaknesses, have at least partly influenced the trajectory of their annual visual art programme. As this research unfolds I note Hal Foster's scepticism about the artist as ethnographer: he posits a danger that ethnography can become another means of reinforcing postcolonial "otherness" and places the artist as ethnographer in the role of "ideological patronage" (Foster, 1995). In seeking to delineate and understand the cultural platforms offered by community festivals in the Gaeltacht I am also trying to understand the culturally specific circumstances that have influenced my own professional development (circumstances which to an extent are inscribed in my own practice), not a distant exoticised other. Nonetheless I bear in mind that any ethnographical process is a creation of a "common construct" between informant and ethnographer, a result of "painstaking conversation with continuous mutual control" (Pinxten, 1997; Rutten \& Van Dienderen, 2013).

\section{FESTIVALS: BACKGROUND, STRUCTURE AND ETHOS}

Féile Tradphicnic, a traditional music festival, is a bilingual annual event based in the small coastal town of An Spidéal, Co Galway. The festival is relatively newly established; founded in 2012 as a two-day event, it subsequently expanded to a threeday program in 2015 . It is marketed towards both the local community and tourists to the area, with a strong bilingual social media presence. It is organised by a voluntary committee and is publically funded. Additional money is raised by fund-raising events throughout the year and donations from local businesses. The festival has a "pay-whatyou can" policy, i.e. none of the events is ticketed but festival attendees are encouraged to donate towards the festival costs, and volunteers circulate throughout the festival grounds with donation buckets. The festival is highly dependent on volunteer support. ${ }^{13}$

The festival was founded by Bridge Barker in order to address a lack of family-friendly traditional music festivals in the Connemara Gaeltacht during the summer. The committee consists of four members, including Bridge Barker as chairperson. Her 
personal experiences (as a fan of traditional music and the parent of a young family) of the high cost and lack of activities associated with traditional music festivals strongly influenced the multi-disciplinary approach of Traidphicnic Festival. Bridge's personal background also influenced the festival's bilingual language policy. She was born in Brighton, in the UK, and English was her first language, though her father is originally from the Connemara Gaeltacht. She herself emigrated to Connemara in 1996 and vividly remembers feeling excluded from normal community activities by her lack of Irish at the time. The decision to run bilingually arose from a wish to be inclusive to both language learners and those with no Irish; ${ }^{14}$ and allowed the festival to cater culturally for a local Irish speaking demographic, incomers to the area with little or no Irish and a wide English-speaking tourist demographic.

Féile Pléaráca ran between 1991 and 2014, and was disbanded in 2015 due to difficulties in securing adequate funding. Therefore, the years under consideration here (2010-2015) were towards the end of its life-span. The festival operated monolingually and was primarily aimed at the local Irish-speaking community, with all publicity material solely in Irish. Initially run as a twelve-day annual festival, Féile Pléaráca covered a large coastal area from Barna to Carna (c $78 \mathrm{~km}$ ) in the Connemara Gaeltacht, encompassing Ceantar na n-Oileán and the Aran Islands. By 2010 (the beginning of this research timeframe) it had scaled down to a three-day event, but still operated annually. By 2010 it had also embraced a nomadic approach, and was held in a different location within that wider area from year to year, e.g. focusing geographically on the Aran Islands one year, Ceantar na n-Oileán another year and so on. ${ }^{15}$

The festival was founded initially as a grass-roots, community initiative with the dual aim of combating the decline of the Irish language in the area, and providing a cultural festival to promote the traditional and contemporary arts. Meta Uí Mháille states that "An Ghaeilge ba cúis leis / The Irish language was the impetus behind it" and explains that a recently published report on the weakened state of the Irish language in Gaeltacht areas had directly led to community action through the founding of Pléaráca. The focus therefore was on the cultural needs of the local Irish speaking community, with the festival timetabled to avoid peak tourist season. Gearóid Denvir, writing in 2002, describes Pléaráca as "a celebration of selfhood, of personal and community identity and not a contrived pseudo-cultural show put on to satisfy the tourist gaze..." (Denvir, 2002: 40). However, though local audiences were the festival's first priority it also had a national and international profile, with some overseas emigrants annually returning home to participate in the festival, and an audience also attending from other parts of Ireland. Over the wider lifespan of the festival it also cultivated connections with minority language festivals internationally, in Wales and Scotland. ${ }^{16}$

The festival was funded by community sponsorship ${ }^{17}$ as well as public funding from Údarás na Gaeltachta, the regional authority for the Gaeltacht. The festival was closely linked ${ }^{18}$ to the work of the community arts organisation Pléaráca Teo. Founded in 1993, Pléaráca Teo. was funded initially by the EU Horizon scheme and subsequently by the Community Development Scheme run by the Dept. of Community Rural, Gaeltacht 
Affairs. ${ }^{19}$ Pléaráca Teo had both social and cultural aims, e.g. to assist socially disadvantaged groups, provide training, raise awareness of the Irish language and heritage amongst younger people, and combat poverty. It is clear that Féile Pléaráca's impetus to take action against the decline of Irish-speaking communities manifested as activism across a broad spectrum of interlinked cultural and socio-economic contexts.

\section{Visual arts in the festival archives}

An initial examination of the Traidphicnic and Pléaráca archives shows an annual engagement with the visual arts by both festivals. Digital copies of brochures, posters and programmes $(2012$ - 2015) from Féile Traidphicnic were examined, containing brief bilingual records of scheduled events for the festivals. A survey of these materials shows that both the quantity of visual art advertised, and the prominence given to it on the program, expanded every year from 2012 to 2015 . While no visual art event was advertised on the official festival program for 2012, it seems that an art exhibition was held along with an art workshop for children (Barker, interview 2017). In 2013 an art installation was listed on the program under the heading "On-going events". In 2014 the visual art content had expanded dramatically to include an exhibition by a local artists' collective, an exhibition of photography, a large-scale outdoor art installation and art workshops for children and adults, and a children's art exhibition. Similarly, in 2015 a large variety of visual art events took place: a community art exhibition, two photography exhibitions over three venues, a large-scale outdoor art installation and art workshops for children and adults. In both 2014 and 2015 the visual arts merited a dedicated section on the programme, under the bilingual heading "Cosán Ealaíne / Art Trail". Most but not all of the artists involved were based in the Connemara Gaeltacht.

Archive materials from Féile Pléaráca were examined for the years 2010-2014, and consisted of black and white photocopies of original festival programmes. As with Féile Traidphicnic, only very brief listings were included in the programme: venue and artist or community group. ${ }^{20}$ In the case of Féile Pléaráca programmes were monolingual, with all material in the Irish language. In the years under consideration the number of visual arts exhibitions in the programme remained consistent, with 1-2 visual art events. Each year with the exception of 2013 included a children's art exhibition (school children, usually working with either one or two professional artists.) In 2010 the programme included an exhibition of sand sculpture at the beach. In 2011 a photography exhibition took place of photos gathered from local communities (no specific artist / curator is mentioned). In 2012 a group exhibition of Connemara artists is advertised. In 2013 a solo visual art exhibition from an emerging artist was held, and in 2014 a solo show with photography from an established artist. All of the artists involved were based in the local area.

Interviews with festival organisers provide important context to these brief archival records. The visual arts were included in the Féile Traidphicnic line-up to provide an alternative activity for festival attendees (especially for those uninterested in traditional 
music) and to create a "real festival atmosphere". ${ }^{21}$ Participatory art, or art with a strong element of public interaction, was valued as offering people the opportunity to "have a go" and engage with the visual arts in a welcoming, non-intimidating environment. The visual arts were perceived as offering a family-friendly activity that supported the ethos of the festival. "You can create some art with your kids and you can have a go, there is always the element of surprise, you never know what's going to happen which is great..." (Barker, interview 2017). The visual arts component in the program grew annually in the years surveyed, and was given correspondingly more prominence in the publicity material. However, the main emphasis of the festival remained on traditional music, with the visual arts regarded as enhancing the overall festival experience, and included in a festival ethos of cultural inclusion and accessibility.

No formal criteria were in place for selecting artists for Féile Traidphicnic; however, as discussed, there was an emphasis on showcasing art that was participative in nature and encouraged a sense of fun and excitement at the festival. The overall visual art element of the festival grew in an organic, unplanned way, with input from local visual artists, including myself. Suggestions for art activities were warmly welcomed by the festival director, and efforts made to accommodate new ideas. Both professional and amateur visual artists participated during the years surveyed, with many of the same artists returning from year to year.

The motivation for incorporating the visual arts in Féile Pléaráca was strongly tied to achieving the social and cultural aims of Pléaráca Teo. In discussion with Meta Uí Mháille the definition of what constituted the visual arts in the context of the festival was wide-ranging. References to the visual arts programming of Pléaráca crossed many disciplines and throughout the extended lifespan of the festival incorporated painting, stained glass, pantomime, street theatre, crafts, and archival community photography. In this broad sense the visual arts were perceived as giving an important platform to the work of Pléaráca, ${ }^{22}$ with the aim of drawing in members of the local community, and promoting creativity in younger people. On a wider level Pléaráca's use of the arts could be understood as a reaction to a sense of threatened community discussed by Kwon and Denvir, and the festival's emphasis on visual creativity across many genres seen as a means to generate a vibrant, locally rooted, community identity.

While no formal artistic criteria were put in place by Féile Pléaráca the work carried out by Pléaráca Teo heavily influenced the selection of artist and artworks for the festival. Historically, summer camps, school projects and training schemes run by the Pléaráca Teo organisation throughout the year fed into work ultimately exhibited at the festival, and in the last years of the festival this ethos is still evident in the annual exhibition of work arising from projects with local schoolchildren. An emphasis on providing artsbased employment opportunities for members of the local community, and reflecting and supporting the cultural heritage of the local area, arose also from the developmental remit of the Pléaráca organisation. The Pléaráca festival arts programme therefore arose from a complex framework that sought to empower and sustain community in the widest sense, culturally and economically. 
In the years surveyed both festivals used a wide range of non-traditional exhibition spaces, including a golf club, local national schools, community halls, office space, pubs, a cafe and a library. A gallery space was available to Pléaráca in in 2013 (when the festival took place on Inis Óirr); otherwise both festivals used whichever spaces they could access locally. In addition to these community venues, Féile Traidphicnic also made extensive use of outside spaces, holding open-air visual art events during the festival, in the grounds of Spiddal Craft Village and by Trá na mBan (a beach located across the road from the Craft Village) in the years 2013 - 2015.

\section{Personal Experience}

Féile Traidphicnic: In 2014 as a result of an informal conversation with festival director Bridge Barker I agreed to participate in the festival. I was pleased to be involved as I had been struggling to find a supported creative platform for my visual art practice locally, and I felt that this was an opportunity to experiment with new formats. I subsequently invited three artists to work collaboratively to produce work for the festival. The artists in question were all Galway-based rather than Gaeltacht-based. Because my rented art studio at the time was located in Galway city my artist peer network was city based and generally English speaking: this clearly had the potential to influence the linguistic dynamics of the art component of the festival. The work we produced drew on our own research interests and considerations of what might succeed aesthetically and practically in an outdoor festival setting, taking into account changeable weather conditions, a lack of shelter and a multigenerational festival audience. The final piece consisted of a large-scale sculptural structure that functioned as walk-in outdoor camera obscura, and an outdoor clay-based installation and workshop. While no curatorial framework was offered by the festival, strong practical support in terms of volunteer help and the planning of logistics was gratefully received. The exhibition site was continuously busy as free workshops and demonstrations (an integral part of the artworks) attracted a large number of children and parents.

Initially the festival was unable to offer any funding as payment for visual artists had not been budgeted for by the committee. However, independently of the festival, I applied for local council funding to contribute towards the material costs of making work. Ultimately the festival did unexpectedly provide a small artist fee for the group when they were left with a surplus budget after all festival expenses were accounted for. In 2015 we were invited back, again with a very open invitation to participate in the festival; however, this time the process was slightly more formalised: we submitted a budget beforehand and received an assurance of some level of funding, and again I augmented this by applying elsewhere to cover costs. Over the next few years, as the visual art strand in the festival developed, the payment of artist fees and costs by the festival became standard practice.

Féile Pléaráca: My association with Féile Pléaráca was as an exhibiting artist in 2013. I was approached by the organisers to participate in the festival, set that year on the 
island of Inis Oírr. They had been looking for someone locally-based for the festival and the regional Arts Officer Muireann Ní Dhroighneán had put my name forward as I had recently moved back into the area after some time completing postgraduate study abroad. Again I was very happy to have a chance to show my work locally as there were so few opportunities to do so and I felt I lacked a strong local cultural network. As with Féile Traidphicnic the invitation to participate as an exhibiting artist was a very open one without the constraints of theme, or curatorial input from the festival. No artist fee was offered, but travel costs and some printing costs were covered.

The venue was a small white cube space in the Áras Éanna Art Centre on Inis Óirr (a multidisciplinary venue), and I personally installed the artwork as the art centre's staff capacity was limited. My final artwork was a floor-based installation consisting of multiples of small sand sculptures and photographic prints. The festival provided an official opening as part of the festival line-up and invited a guest speaker. It was my first experience of a supported Irish-language context for my work, where all stages of the exhibiting process, from initial discussions, to logistical planning and the official opening, were carried out monolingually, in Irish. It was a formative experience in that it opened up the possibility of creatively sustaining my arts practice within the framework of the Gaeltacht. The well-attended official opening created a reflective social space to present the work, and an opportunity to be introduced to other Irish-speaking cultural producers within the wider community.

\section{Key Research Findings}

Both Traidphicnic Festival and Pléaráca Festival included visual art events in their festival line-up in each applicable year surveyed by this research $(2010-2015)^{23}$. Over this time frame Traidphicnic greatly increased both their visual art component, and the prominence given to the visual arts on publicity material. This was partly influenced by my own input, coupled with Traidphicnic's rapidly expanding program over the years surveyed. In the same time-frame Pléaráca's visual art component remained constant, offering 1-2 events each year.

A strong wish to engage with community was a key feature of both festivals in the years surveyed, reflected in exhibitions and art workshops aimed at children and the inclusion of amateur as well as professional visual artists. Both festivals drew heavily on community resources in order to find venues for exhibitions, and Féile Traidphicnic in particular turned towards the use of open-air sites (out of necessity) as its visual art component grew. In this respect these Gaeltacht based festivals reflect the general condition of Irish festivals, dependent on temporary access to provisional communal spaces (Goh, 2004: 7). In mainland Connemara, in the absence of gallery spaces, ${ }^{24}$ these provisional spaces also reflect the permanently ad hoc nature of exhibiting for visual artists in the area. In a festival context the uncertainty surrounding exhibiting artworks in the open air in variable weather conditions imposed limitations on what 
could practically and safely be exhibited; however, the opportunity to exhibit in the heart of a festival also created new opportunities for public visibility and engagement.

Féile Traidphicnic is aimed at both the local and tourist demographic and is run bilingually with an emphasis on welcoming local and non-local attendees whatever their capacity in the Irish language. This is reflected in their visual art programming in the years surveyed, through their inclusion of non-Gaeltacht based and non-Irish speaking visual artists in their programme. Again my own input (and particularly the artist-peer network on which I drew for participants) was among multiple geographical and linguistic factors that influenced this. Traidphicnic's bilingual policy meant that it was easy to navigate for non-Irish speaking artist participants and An Spidéal, where the festival is held, is geographically near the edge of the Gaeltacht area, only a short drive from Galway city. The bilingual policy was also a factor in the rapid expansion of the arts programme as it gave the festival access to an expanded pool of artists to work with.

Pléaráca positioned itself as an Arts Festival for, and by, the local Irish-speaking community and as such was perceived as culturally authentic by academic commentators such as Gearóid Denvir. Arising from this, the festival's selection process, monolingual language policy and cultural aims emphasized the support of local Irish-speaking artists. Consequently, in the years surveyed it depended on a relatively small pool of exhibiting artists.

\section{Conclusions}

My initial findings indicate that the visual art content of these two festivals was influenced by their positioning as Gaeltacht community festivals. From my initial survey of archive and interview sources it is clear that Féile Pléaráca's initial impetus to take action against the decline of Irish-speaking communities, and the wider social, political and economic remit of Pléaráca Teo (its parent organization) had a fundamental effect on their arts programming, the visual arts included. In this respect the festival's arts programming could be understood as a reaction to a sense of threatened community discussed by Kwon and Denvir, where the arts become a means to reinforce identity and a sense of distinctiveness. The visual in this sense becomes a mirror to reflect and augment a monolingual Gaeltacht community identity and a means to "sustain the cultural and historical specificity of place" (Kwon, 2004: 109). It is clear however that over the longer lifespan of the festival this sense of specificity of place reached beyond geographical limits and encompassed a sense of extended community with overseas emigrants and other minority language communities internationally. The discursive site embraced by the festival extended far beyond the physical boundaries of the Connemara Gaeltacht area, complicating the idea of what constitutes the local.

It is also clear that the role of the visual arts was not a simple one in Pléaráca's efforts to sustain community. The impetus to strengthen and reinforce cultural community is 
reflected also in the provision of non-prescriptive Irish-speaking cultural contexts for visual artists to operate in, alongside other, more traditional art forms. This initial survey also indicates that the focus on the use of the visual to deepen community bonds meant that it is difficult to differentiate clearly between amateur, professional or educational activities in the festival programming, with the visual arts often operating on a continuum between categories and across art disciplines. Parallels could be drawn here with Grizedale Arts and their complex engagement between festival staging, artmaking and building community, albeit working in a different realm, outside of the mainstream artworld recognition attained by the Grizedale organisation. As discussed earlier, the complexities of such socially engaged durational projects mean aesthetic analysis and evaluation is particularity challenging, and perhaps even more-so where the lead organisation operates outside of fine art contexts. In order to understand what Claire Bishop has termed the "affective complexity" of the visual arts within these extended community projects, it is important to trace the long-term trajectory of the visual arts strand in relation to the wider aims of the festivals involved, as well as to consider the aesthetic content of individual art works shown from year to year.

Féile Traidphicnic was from its inception aimed at both a local and tourist demographic and this influenced the visual art content of the festival. On a wider level Traidphicnic's vision of inclusivity seems to complicate narratives around cultural authenticity outlined by John Walsh and Gearóid Denvir, with the festival's activities located outside categorizations of authenticity that rely on pitting the tourist gaze against the local gaze. Open to bilingual programming and offering a platform to both local and nonGaeltacht based artists, the festival might be said to reflect the social reality of a bilingual community where Irish is the dominant language and in which English is the secondary language. The cultural goal of the creation of a fun, welcoming atmosphere in a bilingual Gaeltacht environment to a large degree shaped the visual art content exhibited. Although no formal curatorial policy was in place, the festival's focus on cultural and social accessibility prioritised the programming of visual art projects with a high level of public engagement as the festival programme evolved.

In her book One Place After Another Miwon Kwon calls for a renegotiation of the relationship between art production and communities, asking, "What would it mean now to sustain the cultural and historical specificity of place (and self) that is neither a simulacra pacifier or a wilful invention?" (Kwon, 2004:109). In the case of Féile Pléaráca and Féile Traidphicnic, it seems that cultural specificity of place is sustained through complex and engaged consideration of what it means to be part of a Gaeltacht community, negotiating ideas of authenticity, inclusivity and linguistic local identity. Both of these festivals are deeply embedded in community, and provide important records of a durational engagement with the visual in the Connemara Gaeltacht community. As Getz points out, modern festivals are managed entities that encompass multiple goals, stakeholders and meanings (Getz, 2010: 2) and as such need to be considered holistically in community and institutional contexts. More detailed archival research over a longer timeframe needs to be carried out to fully understand the role played by the visual arts, and the forces shaping the visual art content of these festivals. More attention also needs to be given to the situated experience of artists and 
audience at these events. However, this initial survey seems to indicate that the discursive site of the Gaeltacht, bounded by linguistic and cultural concerns rather than geographical parameters, has largely influenced festival arts programming in these instances. The different conceptions of what constitutes a strong Gaeltacht community (monolingual or bilingual) and a desire to strengthen and reinforce these conceptions of community has had a notable influence on the visual art content of these festivals.

\section{Bibliography:}

ATKINSON, P.: COFFEY, A. - Analysing documentary realities. In D. Silverman (Ed.), Qualitative research, London: Sage: 45-62. (2004). (cited in "Esource -Behaviour and Social Sciences http://www.esourceresearch.org/eSourceBook/QualitativeMethods/5Documents/tabid/268/De fault.aspx

BEO [Online Magazine] - Agallamh le Meta Úí Mháille, Vol 52, Aug 2005

http://www.beo.ie/alt-plearaca-chonamara.aspx, accessed 05/03/2017

BHREATHNACH-LYNCH, Sighle - Eire/Land. Ed. Vera Kreilkamp. Chicago: McMullen Museum of Art, Boston College/University of Chicago Press, 2003. ISBN-10:1892850052

BISHOP, Claire, Artificial hells: Participatory art and the politics of spectatorship, Verso Books, London, 2012. ISBN- 13: 978- 1- 84467- 690- 3

BREWER, John D, Ethnography, Open University Press, Buckingham / Philadelphia, 2005. ISBN-10: 0335202691

CENSUS 2016, - The Irish Language [Online Irish Census Findings by the Irish Central Statistics http://www.cso.ie/en/media/csoie/releasespublications/documents/population/2017/7._The_Ir ish_language.pdf, accessed, February 2019

DENVIR, Gearóid, "The Language Implications Of Mass Tourism in Gaeltacht Areas" , New Hibernia Review / Iris Éireannach Nua, ISSN.1534-5815. Vol. 6, No. 3 (Autumn, 2002), pp. 23-43

DEL BARRIO, M. J.; DEVESA M; HERRERO L. C. - Evaluating intangible cultural heritage: The case of cultural festivals'. City, Culture and Society, 3(4), 235-244, 2012 http://course.festivals.coplacdigital.org/wp-content/uploads/2016/01/delbarrio.pdf, accessed 20/05/2019

DEUTSCHE, Rosalyn. Evictions: Art and spatial politics. Cambridge, MA: Mit Press, 1996

https://monoskop.org/images/0/0a/Deutsche_Rosalyn_Evictions_Art_and_Spatial_Politics.pdf, accessed 20/05/2019

FOSTER, Hal - The Artist as Ethnographer, 1995, e-resource

https://monoskop.org/images/8/87/Foster_Hal_1995_The_Artist_as_Ethnographer.pdf, accessed 06/03/2017

GETZ, Donald - "The nature and Scope of Festival Studies", International Journal of Event Management Research ISSN 1838-0681, Volume 5, Number 1, 2010

http://ijemr.org/wp-content/uploads/2014/10/Getz.pdf

$\mathrm{GOH}$, Fiona - Irish Festivals, Irish Life: celebrating the wealth of Ireland's festivals, Association of Irish Festival Events, 2004, http://www.aoifeonline.com/uplds/Goh_Final_Report.pdf

GUTHRIE, Gerard - Basic research methods: an entry to social science research, Sage, Los Angeles, 2010. ISBN-13: 9788132104575 
GRIZEDALE ARTS, [Website] - What We Do, http://www.grizedale.org/about/ accessed 05/03/2017.

KWON, Miwon - One Place after Another: Notes on Site Specificity, October, ISSN: 0162-2870. Vol. 80. (Spring, 1997), pp. 85-110.

KWON, Miwon - One Place After Another: Site-Specific Art and Locational Identity, The MIT Press, 2004. ISBN-13: 9780262612029

MACCANNELL, Dean - The tourist: a new theory of the leisure class, Berkeley, Calif. London: University of California Press, 1999. ISBN-13: 9780520280007

NASH, C. - The West of Ireland and Irish Identity. Ed. Barbara O'Connor and Michael Cronin. Tourism in Ireland, a critical analysis. Cork: Cork University Press. 1993. ISBN-13: 9781859180068

NÍ CHRíOCHÁIN, Majella, An Audit on the Arts in the Gaeltacht, 2010 http://www.ealain.ie/wp-content/uploads/pdf/audit-of-the-arts-in-the-gaeltacht-2010.pdf, accessed 05/03/2017

O'CONNOR, Barbara, Cronin, Michael (eds), Tourism in Ireland: a critical analysis, Cork University, 2006

Ó HÉALLAITHE, Donncha - From Language Revival to Survival, 2004, http://anghaeltacht.net/ctg/altveritas.htm

O'NEIL, Paul; Doherty Claire (eds) - Locating the Producers, Amsterdam, Valiz, 2011. ISBN-13: 9789078088516

O MAHONY, Deirdre - New Ecologies Between Rural Life and Visual Culture in the West of Ireland: History, Context, Position, and Art Practice. U. of Brighton, UK, 2012

QUINN, B. - Problematising 'festival tourism': Arts festivals and sustainable development in Ireland. Journal of Sustainable Tourism, 14(3), 2006, 288-306.

https://www.academia.edu/6610813/Problematising_Festival_Tourism_Arts_Festivals_and_Sus tainable_Development_in_Ireland, accessed 25/05/2019

RICHARDS, G. - The festivalization of society or the socialization of festivals? The case of Catalunya. In G. Richards (Ed.), Cultural Tourism Global and Local Perspectives (pp. 257280). New York: The Haworth Hospitality Press, 2007.

https://www.academia.edu/4523241/The_Festivalization_of_Society_or_the_Socialization_of_F estivals_The_Case_of_Catalunya, accessed 25/05/2019

SCOTT, Yvonne, The West as Metaphor, [Catalogue Essay], Royal Hibernian Academy, 2005

SILVERMAN, David, Interpreting Qualitative Data: Methods for Analyzing Talk, Text and Interaction, Sage Publications, London, 2006

SILVERMAN, David - Esource: Behaviour and Social Sciences Research, Retrieved May 2017 from http://www.esourceresearch.org/eSourceBook/QualitativeMethods/5Documents/tabid/268/De fault.aspx

TROCHIM, William M. K. - Research Methods Knowledge Bass - Qualitative Methods, 2006 Retrieved May 2017 from http://www.socialresearchmethods.net/kb/qualmeth.php WALSH, John - Díchoimisiúnú Teanga: Coimisiún na Gaeltachta 1926, Cois Life, 2002 ISBN: 9781901176322 WALSH, John - Contest and contexts: the Irish language and Ireland's socio-economic development, Oxford, Peter Lang, 2011. ISBN-13: 9783039119141 


\section{Biographical note}

Nuala Ní Fhlathúin is from the Leitir Móir area in Co Galway, Ireland. She received a BFA in 2008 and an MFA in Sculpture from the University of Washington in Seattle in 2011. She has established a strong track record as a contemporary art practitioner in the Connemara Gaeltacht and further afield, developing an art practice around questions of place, language and visuality. She has been the recipient of numerous competitive Bursaries, Awards and Commissions, most recently a 2019 project award from the Arts Council of Ireland. Other recent awards include support from Ealaín na Gaeltachta, Oireachtas na Gaeilge, Galway County Arts Office. Residency awards include the Heinrich-Boll Residency in Achill, Trasnú Residency in Tibilissi, Georgia, Samkura Residency in Benfita, Portugal and a 6-week research residency in Friesland, Netherlands as part of TOSTA (initiated by the European City of Culture 2016). She also works as an independent curator, researcher and art administrator, and is currently engaged on a practice-based PhD at the Centre for Creative Arts and Media, Galway Mayo Institute of Technology, supported by a GMIT RISE Scholarship

\footnotetext{
1 This research was supported by a RISE postgraduate research scholarship from the GalwayMayo Institute of Technology.

2 In the most recent audit of the arts in Gaeltacht areas, commissioned by the regional arts organisation Ealaín $\mathrm{Na}$ Gaeltachta, the Connemara area was singled out for the notable underdevelopment of visual arts facilities in the area (Ní Chríocháin, 2010).

${ }^{3}$ A further dramatic drop in the number of Irish speakers in the 2016 census generated numerous newspaper headlines, with the Irish Times reporting that the $11 \%$ drop in daily speakers in the Gaeltacht confirmed the "decline of Irish in its traditional heartland", https://www.irishtimes.com/opinion/census-shows-we-must-rethink-our-approach-to-irish-andthe-gaeltacht-1.3040392

4 "...the siting of art in "real" places can also be a means to extract the social and historical dimensions out of places to variously serve the thematic drive of an artist, satisfy institutional demographic profiles, or fulfill the fiscal needs of a city." (Kwon, 2004:105).

${ }^{5}$ She asks, "What would it mean now to sustain the cultural and historical specificity of place (and self) that is neither a simulacra pacifier or a wilful invention?" (Kwon, 2004:109).

6 "the contradictory pull between a stable knowable place, and a state of flux, an event in process" (O'Neill, Doherty, 2011: 2-3).

7 http://www.grizedale.org/about/, accessed April 2017.

8 They state: "art and artists operate in contexts far removed from art worldly spaces and instigate use-value practices, which have specific tools, means and manifestations that relate to their new contexts rather than result in the making of so-called art" (O'Neill, Doherty, 2011:96).

9 In the most recent audit of the arts in Gaeltacht areas, commissioned by regional arts organisation Ealaín $\mathrm{Na}$ Gaeltachta, the Connemara area was singled out for the notable underdevelopment of visual arts facilities in the area (Ní Chríocháin, 2010).

10 In conversation with Muireann ní Dhroighneáin, arts officer for the Connemara Gaeltacht.

11 "While primitive celebrations might have sprung up organically, in concert with agricultural and climatic cycles, modern festivals are mostly created and managed with multiple goals, stakeholders and meanings attached to them" (Getz, 2010:7).

12 The survey was conducted in 2004 and sought data from 2002 (or 2001 in the case of biennials), with 103 festivals responding out of a total of 462 (Goh, 2004).

13 Information sourced from interview with Bridget Barker, Festival Director for Féile Traidphicnic, 27 March 2017.
} 
14 "Níl Gaeilge ag chuile dhuine agus má tá tú ag foghlaim tá sé handy má tá tú ag iarraidh oibriú amach can atá ag dul ar aghaidh ar póstaerí / Not everybody has Irish and if you are a learner or if you have no irish it (bilingual signage) is handy to work out what is going on" Bridge Barker, Personal Interview, January 2019.

15 Information sourced from interview with Meta Uí Mháille, former Community Officer with Pléaráca Teo, 15 March 2017.

16 Uí Mháille, personal email correspondence Feb 2019.

17 In the form of paid advertisement for local businesses and organisations in the festival brochure (Uí Mháille, email correspondence Feb 2019).

18 Pléaráca festival initially operated with an independent organizing committee but this role was eventually taken over by Pléaráca Teo, with help from local community members (Uí Mháille, email correspondance Feb 2019).

19 http://www.beo.ie/alt-plearaca-chonamara.aspx

20 At times the term "taispeántas" is used in the programming to denote "display" rather than "exhibition", e.g. a display of local folklore (Taispeántais Béaloideais, Féile Pléaráca 2010).

21 "Tá said (na físealaíona) an-tabhachtach, muna raibh said ann ní bheadh féile ceart i gceist". They (the visual arts) are very important, without them it wouldn't be a proper festival (Barker, interview, 2017).

22 "Físealaíona a thug árdán do obair Phléaráca." The visual arts provided a platform for Pléaráca's work (Uí Mháille, interview, 2017).

${ }^{23}$ Note that Traidphicnic wasn't founded until 2012 and that Pléaráca's last festival was held in 2014.

${ }^{24}$ Although a regional Arts Centre for the Connemara Gaeltacht does exist, it is located on the Island of Inis Oírr, and the 3-hour round trip involved in accessing it by ferry renders it practically inaccessible for day-to-day cultural activities by residents of mainland Connemara. 